\title{
Maternal-conceptus signalling during early pregnancy in mares: oestrogen and insulin-like growth factor I
}

\author{
K. W. Walters, J. F. Roser and G. B. Anderson \\ Department of Animal Science, University of California, Davis, CA 95616, USA
}

\begin{abstract}
Embryonic production of oestrogen is thought to play an important role in conceptus-maternal signalling during early pregnancy in mares, and may be regulated in an autocrine or paracrine fashion by insulin-like growth factor I (IGF-I). In this study, the hypothesis that IGF-I stimulates embryonic oestrogen synthesis, which in turn stimulates uterine IGF-I secretion was tested. Specific sources of IGF-I in the uterine lumen were characterized. Preimplantation embryos, uterine biopsies, and uterine flush fluids were collected on day 13 of pregnancy. Embryos were cultured whole for $24 \mathrm{~h}$, or dispersed and incubated in serum-free culture medium supplemented with androstenedione or testosterone $\left(0-10 \mu \mathrm{g} \mathrm{ml}^{-1}\right)$ and
\end{abstract}

IGF-I (0-100 ng ml-1). Oestrogen synthesis was increased by addition of androgen, but there was no dose-dependent effect of IGF-I. Endometrial explants were cultured for 24,48 and $72 \mathrm{~h}$ in serum-free medium supplemented with oestradiol. IGF-I was measured by radioimmunoassay in embryo-conditioned medium, explant culture medium, blastocoelic fluid, concentrated $(\times 100)$ uterine flush fluid and endometrial-tissue homogenate. Both the embryo and endometrium produced significant quantities of IGF-I, indicating a role for this growth factor in autocrine-paracrine signalling during early pregnancy. However, secretion of IGF-I by endometrial explants was not modulated by oestrogen.

\section{Introduction}

The continuing challenge of embryonic loss during the preimplantation period, and the desire to develop effective in vitro systems for equine embryo culture and manipulation make requisite an increased knowledge of the dynamics of early pregnancy in mares. Current understanding of the first 2 weeks of gestation in domestic animals indicates that the conceptus is an active partner in the successful establishment and maintenance of pregnancy (Roberts et al., 1996). Signals from the horse conceptus during this period ensure selective transport of viable embryos to the uterus (Freeman et al., 1992), maintenance of the progesteroneproducing corpus luteum (Sharp et al., 1989) and preparation of a supportive uterine environment. The prodigious production of oestrogen by the trophoblast of the early equine embryo probably plays a role in these processes.

Oestrogen biosynthesis by preimplantation embryos has been documented in a number of species including horses (Flood et al., 1979; Zavy et al., 1979; Goff et al., 1983; Choi et al., 1997; Walters, 1998), pigs (Perry et al., 1973), donkeys (Heap et al., 1991), camels (Skidmore et al., 1994) and llamas (Powell et al., 1999), and is presumed to participate in critical maternal-conceptus communication. Results of studies in pigs indicate that conceptus-derived oestrogen may serve as the signal for the maternal recogni-

Email: kwwalters@ucdavis.edu tion of pregnancy (MRP)(Bazer and Thatcher, 1977), and influence endometrial protein secretion as well as uterine contractility and embryonic spacing (for review, see Roberts et al., 1993; Geisert and Conley, 1998). In Ilamas, exogenous oestrogen may support extended luteal function (Powell et al., 1999). The precise role of embryonic oestrogen secretion in mares has been difficult to elucidate.

The role of insulin-like growth factor I (IGF-I) as a paracrine-autocrine modulator of steroidogenesis in the pig conceptus was investigated by Hofig et al. (1991). It has been hypothesized that there is a positive 'feed forward system' by which embryonic oestrogen enhances uterine secretion of IGF-I. In turn, IGF-I of uterine (paracrine) or conceptus (autocrine) origin increases the activity of the oestrogen-synthesizing cytochrome P450 aromatase (P450arom) in the embryo (Simmen et al., 1993, 1995). Similar tissue-specific expression patterns for P450arom in preimplantation pig (Conley et al., 1994) and equine (Walters et al., 2000) embryos indicates that these species may share common regulatory mechanisms.

The synthesis and secretion of IGF-I by both the embryo and endometrium underscore the importance of this growth factor in early pregnancy. Uterine expression of IGF-I is widely documented (for review, see Simmen et al., 1995). Expression of the genes for IGF-I and the receptor (IGF-IR) in the preimplantation embryo has been reported for a number of species including cattle (Watson et al., 1992; Schultz and Heyner, 1993), pigs (Letcher et al., 1989), rats (Zhang et al., 1992) and sheep (Watson 
et al., 1994). Little is known about IGF-I synthesis or IGFIR expression by equine embryos.

Oestrogen is known to enhance endometrial secretion of IGF-I in rodents (Murphy et al., 1987; Murphy and Ghahary, 1990) and primates (Adesanya et al., 1996) and it is possible that oestrogen-mediated control of uterine IGF-I represents an important, more universal, paracrine or autocrine signal for support of early pregnancy. Embryonic oestrogen may also increase uterine IGF-I production in mares. IGF-I has been detected in uterine flushes from pregnant mares (Salute and Tucker, 1992), and may play a role in the control of oestrogen production by the equine conceptus. However, the specific sources, quantities, and regulatory mechanisms of IGF-I secretion have not been well characterized.

The goals of the present study were to test the hypothesis that IGF-I stimulates conceptus oestrogen synthesis at the level of P450arom activity, to identify the sources of IGF-I in the uterine lumen and quantify its secretion, and to determine whether oestrogen stimulates equine endometrial secretion of IGF-I.

\section{Materials and Methods}

\section{Embryo collection and tissue biopsy}

Cyclic light horse mares (Equus caballus) were teased daily during two breeding seasons. Mares in oestrus were palpated per rectum to monitor ovarian activity. After the detection of a follicle measuring $\geqslant 30 \mathrm{~mm}$, mares were artificially inseminated on alternate days until ovulation occurred. Ultrasonography was used to confirm pregnancy from 10 days after ovulation onward, and to measure embryo diameter. Blastocyst-stage embryos were collected 13 days after ovulation by transcervical flush (Choi et al., 1997) using $500 \mathrm{ml}$ pre-warmed $\left(37^{\circ} \mathrm{C}\right)$ sterile PBS. Mares were inseminated on subsequent cycles to allow for multiple embryo collections per mare. Over two seasons, 70 embryos were collected from 18 mares. The total flush volume $(500 \mathrm{ml})$ was used to lavage the uterus twice for more complete recovery of luminal proteins, and immediately frozen $\left(-20^{\circ} \mathrm{C}\right)$ until it was concentrated and assayed for IGF-I. After uterine flush and embryo recovery, endometrial tissues were collected by biopsy (Kenney, 1978). Endometrial biopsy tissues were either placed in $1.5 \mathrm{ml}$ PBS and snap-frozen in liquid nitrogen or used immediately in culture experiments. Additional biopsies were collected on day 13 after ovulation from eight mares that were not inseminated so that a comparison could be made of tissue concentrations of IGF-I between pregnant and nonpregnant mares. All tissue samples not used in culture were snap-frozen and stored at $-80^{\circ} \mathrm{C}$ until later homogenization and assay. All procedures on animals followed protocols approved by the University of California, Davis Animal Care and Use Committee.

\section{Embryonic cell culture}

Freshly collected embryos were rinsed three times in
$30 \mathrm{ml} \mathrm{Hank's} \mathrm{balanced} \mathrm{salt} \mathrm{solution} \mathrm{(HBSS;} \mathrm{Gibco,} \mathrm{Grand}$ Island, NY). The blastocoelic fluid was collected by rupture of the embryo and frozen $\left(-20^{\circ} \mathrm{C}\right)$ for later analysis. Collapsed embryos were dissociated by gentle mechanical disruption after addition of $5 \mathrm{ml} 0.25 \%(\mathrm{v} / \mathrm{v})$ trypsin-EDTA solution (Gibco) pre-warmed to $38^{\circ} \mathrm{C}$. At $10 \mathrm{~min}$, fetal calf serum (FCS; Gibco) was added to $10 \%$ (v/v). Cells were centrifuged for $5 \mathrm{~min}$ at $300 \mathrm{~g}$, rinsed three times in fresh HBSS, and resuspended in Ham's F12:Dulbecco's modified Eagle's medium (DMEM) (Gibco) culture medium supplemented with $0.1 \%(\mathrm{w} / \mathrm{v})$ bovine serum albumin (BSA; Fraction V, Gibco), penicillin (100 iu $\mathrm{ml}^{-1}$ ) and streptomycin $\left(100 \mu \mathrm{g} \mathrm{ml}^{-1}\right)$. Cells were plated in standard 24-well culture plates at different cell concentrations and incubated in a humidified atmosphere of $5 \% \mathrm{CO}_{2}$ and $95 \%$ air at $38^{\circ} \mathrm{C}$. Treatments were initiated at the time cells were plated $(t=0 \mathrm{~h})$ and performed in triplicate for each experiment. After culture, cell-conditioned medium was collected and frozen $\left(-20^{\circ} \mathrm{C}\right)$ for later assay. The number and viability of cells were assessed at each period using a haemocytometer and Trypan blue stain.

Three embryos were used and plated at cell concentrations of $5 \times 10^{3}$ to $2 \times 10^{5}$ cells per well to establish a standard number of cells per well for future experiments. Culture medium was collected at $24 \mathrm{~h}$ and total oestrogen accumulation determined by validated radioimmunoassay as described below. In subsequent culture studies, $5 \times 10^{4}$ cells per well was used as a standard cell concentration.

\section{Dose-response studies}

The dose-dependent effects of IGF-I, androstenedione, and testosterone on oestrogen production and P450arom activity were investigated by adding different concentrations of IGF-I (Gibco) and steroids to the culture medium immediately before plating the cells. Stock solutions of androstenedione or testosterone (Steraloids, Wilton, NH) were prepared at concentrations of $100 \mu \mathrm{g} \mathrm{ml}-1$ by dissolving the steroids in $1 \mathrm{ml}$ ethanol, drying under air, and resuspending in culture medium overnight. After sterile filtration through a $0.22 \mu \mathrm{m}$ filter (Millipore Co., Philadelphia, PA), the stock solutions were used to supplement cell cultures at $0.01,0.1,1.0$ and $10.0 \mu \mathrm{g} \mathrm{ml}^{-1}$. After incubation, culture medium was collected and frozen $\left(-20^{\circ} \mathrm{C}\right)$ until assay. For the initial studies, ten day 13 blastocyst-stage embryos were used to determine the effect of IGF-I on oestrogen production in a serum-free culture. IGF-I (Gibco) was added to the culture medium (F12:DMEM, 0.1\% BSA, antibiotics) at $0-500 \mathrm{ng} \mathrm{ml}^{-1}$. Cells were plated at $5 \times 10^{4}$ per well and incubated for 6 , 12, 18 and $24 \mathrm{~h}$. Additional cell cultures were supplemented with $0.0,0.01,0.1,1.0$ and $10.0 \mu \mathrm{g} \mathrm{ml}^{-1}$ androstenedione $(n=4)$ or testosterone $(n=3)$ and incubated for $24 \mathrm{~h}$ to determine the effect of androgen substrate on oestrogen production. Additional IGF-I dose-response studies $(n=4)$ were carried out at a saturating dose 
$\left(1.0 \mu \mathrm{g} \mathrm{ml}^{-1}\right)$ of androstenedione. Cultures were supplemented with IGF-I at 0-100 ng ml-1 and incubated for $24 \mathrm{~h}$.

\section{Whole embryo and endometrial cultures}

For the determination of conceptus secretion of IGF-I, three intact day 13 embryos were used. Freshly collected embryos were washed three times in HBSS and cultured for $24 \mathrm{~h}$ in $50 \mathrm{ml}$ serum-free medium (F12:DMEM, 0.1\% BSA, antibiotics) as described above. Blastocoelic fluid (BF) was collected from an additional nine embryos used for dispersed-cell cultures in previous experiments.

Endometrial explant tissue, recovered by biopsy, was rinsed three times in $30 \mathrm{ml}$ pre-warmed $\left(38^{\circ} \mathrm{C}\right) \mathrm{HBSS}$, cut into pieces of approximately $2 \mathrm{~mm}$ with sterile surgical scissors, and placed in standard 24-well plates (one piece per $2 \mathrm{ml}$ well) in $2 \mathrm{ml} \mathrm{Ham}$ 's F12:DMEM culture medium supplemented with $0.1 \%$ BSA (w/v), penicillin $\left(100\right.$ iu $\left.\mathrm{ml}^{-1}\right)$ and streptomycin $\left(100 \mu \mathrm{g} \mathrm{ml}^{-1}\right)$. Explants were incubated in a humidified atmosphere of $5 \% \mathrm{CO}_{2}$ and $95 \%$ air at $38^{\circ} \mathrm{C}$ for 24,48 or $72 \mathrm{~h}$. After incubation, culture medium was collected and frozen at $-20^{\circ} \mathrm{C}$ until later assay. Explant wet mass was recorded for each treatment well. Cultures were supplemented with oestradiol (Steraloids) from 0 to $10 \mu \mathrm{g} \mathrm{ml}^{-1}$ and incubated for 24 ( $n=3$ experiments), $48(n=3)$ and $72 \mathrm{~h}(n=1)$ to test the ability of oestrogen to stimulate IGF-I production by the endometrium. For each experiment, treatments were performed in triplicate. Data from three experiments were averaged for the 24 and $48 \mathrm{~h}$ periods.

\section{Oestrogen radioimmunoassay}

Oestrogen was measured in samples of ether-extracted medium as described by Pinaud et al. (1991) with a slight modification. Samples were extracted in $2 \mathrm{ml}$ fresh ether, and cell culture medium (F12:DMEM, 0.1\% BSA), rather than plasma, was used to prepare assay controls and test extraction efficiency. The antiserum (Niswender number 244), characterized by England et al. (1974), is highly specific for oestradiol and has 3\% crossreactivity to oestrone and oestriol. The crossreactivity to testosterone, progesterone, and androstenedione is $<0.1 \%$. The limit of sensitivity of the assay was $10 \mathrm{pg} \mathrm{ml}^{-1}$. Intra- and inter-assay coefficients of variation were $4.8(n=28)$ and $15.5 \%$ $(n=28)$, respectively.

\section{Insulin-like growth factor I radioimmunoassay}

Insulin-like growth factor I was measured in concentrated $(\times 100)$ uterine flushings, culture medium, endometrial tissue homogenate, and BF by a validated, heterologous double antibody radioimmunoassay (Jordan, 1995). Human recombinant IGF-I (Gibco) was used to prepare assay standards $\left(0.25-64 \mathrm{ng} \mathrm{ml}^{-1}\right)$ and to iodinate IGF-I (Baxter et al., 1982). Radiolabelled IGF-I (125I-labelled IGF-I) was diluted in assay buffer $\left(0.03 \mathrm{~mol} \mathrm{Na}{ }_{2} \mathrm{HPO}_{4} \mathrm{I}^{-1}\right.$, $0.25 \%(\mathrm{w} / \mathrm{v}) \mathrm{BSA}, 0.01 \%(\mathrm{w} / \mathrm{v})$ EDTA, $0.02 \%(\mathrm{w} / \mathrm{v})$ protamine sulfate, $0.02 \%(w / v)$ sodium azide, $\mathrm{pH} 7.5$; Sigma, St
Louis, MO) to 20000 d.p.m. per $200 \mu$ l. The primary antibody, anti-IGF-I-somatomedin-C rabbit antisera (NIDDK, UB3-189), was diluted 1:3000 in assay buffer. The secondary, precipitating, antibody solution was $0.1 \%(\mathrm{v} / \mathrm{v})$ normal rabbit serum (NRS) and $1 \%(\mathrm{v} / \mathrm{v})$ goat anti-rabbit gamma globulin (Antibodies Inc., Davis, CA) in 5\% polyethyleneglycol assay buffer. Samples $(200 \mu \mathrm{l})$ and standards $(200 \mu \mathrm{l})$ were subjected to acid-ethanol $(87.5 \%$ ethanol, $\left.12.5 \%(\mathrm{v} / \mathrm{v}) 2 \mathrm{~mol} \mathrm{HCl} \mathrm{^{-1 }}\right)$ cryoprecipitation, and subsequently neutralized with 0.855 mol Tris $\mathrm{I}^{-1}(5: 2 \mathrm{v} / \mathrm{v})$. Neutralized samples and standards were stored at $4{ }^{\circ} \mathrm{C}$ for up to 2 weeks before assay. For radioimmunoassay, $100 \mu \mathrm{l}$ primary antibody solution was added to $100 \mu \mathrm{l}$ aliquots of samples and standards in polypropylene centrifuge tubes. After incubation for $1 \mathrm{~h}$ at room temperature, $200 \mu \mathrm{l}{ }^{125} \mathrm{I}$ labelled IGF-I (20000 d.p.m.) was added to all tubes and allowed to equilibrate for $24 \mathrm{~h}$ at $4^{\circ} \mathrm{C}$. One millilitre of the secondary antibody solution was added and incubated for $1 \mathrm{~h}$ at room temperature, and tubes were centrifuged at $2500 \mathrm{~g}$ for $35 \mathrm{~min}$ to precipitate the bound fraction. Radioactivity in the resultant pellet was counted on an automated gamma counter. The limit of sensitivity was $1.55 \mathrm{ng} \mathrm{ml}^{-1}$. Intra- and interassay coefficients of variation were $2.74(n=4)$ and $8.86 \%(n=4)$, respectively.

\section{Measurement of IGF-I in uterine flushings, endometrial biopsies, blastocoelic fluid, and whole embryo and endometrial explant cultures}

Uterine flushings $(500 \mathrm{ml})$ were thawed to $4^{\circ} \mathrm{C}$ and concentrated approximately 100-fold using a Centriprep-3 3000 molecular weight-cut-off filter in an Amicon filtration system (Amicon, Beverly, MA). Samples were stirred gently and continuously during the filtration. All procedures were carried out at $4^{\circ} \mathrm{C}$. Subsequently, flush fluid concentrates were frozen $\left(-20^{\circ} \mathrm{C}\right)$ until assay. Insulin-like growth factor I concentrations were measured by radioimmunoassay and multiplied by the sample volume to estimate the total IGF-I in the uterine lumen. Endometrial biopsies were thawed and immediately homogenized for $3 \mathrm{~min}$ in $1.5 \mathrm{ml}$ PBS. The homogenate was centrifuged at $2500 \mathrm{~g}$ for $2 \mathrm{~min}$, and the supernatant was assayed for IGF-I and total soluble protein (Bio-Rad protein assay; Bio-Rad, Richmond, CA). IGF-I concentrations were recorded as ng IGF-I mg-1 total protein to normalize data between tissues. The BF from nine freshly collected (not cultured) embryos was assayed for IGF-I by radioimmunoassay. The total IGF-I in the blastocoele was estimated by calculation of blastocoele volume $\left(v=4 / 3 \pi r^{3}\right)$. Secretion of IGF-I by the whole embryo or endometrial explants was determined by assay of IGF-I accumulated in the culture medium. Tissue wet mass was used to normalize endometrial secretion data on a ng $\mathrm{mg}^{-1}$ basis.

\section{Statistical analysis}

Data are expressed as mean \pm SEM. Statistical analysis was performed using Statistical Analysis Systems (SAS) 
software (SAS Institute Inc., Cary, NC). The relationship between oestrogen production and number of cells was determined by simple regression. Comparisons of mean oestrogen production at different periods and in doseresponse studies were analysed by two-way analysis of variance (ANOVA), and post-hoc analysis was by paired $t$ tests of least squares. Comparisons of mean IGF-I production in oestrogen dose-response studies were analysed by ANOVA with post-hoc analysis by paired $t$ tests of least squares means. A $t$ test was used to compare the IGF-I content of endometrial tissue from pregnant and non-pregnant mares. Differences were considered significant if $P<0.05$.

\section{Results}

\section{Cell culture validation}

Oestrogen production by dispersed embryonic cells in culture increased with number of cells in a linear fashion $\left(r^{2}=0.88 ; y=117.7+0.027 x\right)$. Mean oestrogen production increased during a $24 \mathrm{~h}$ incubation from 161 to $5385 \mathrm{pg}$ as the corresponding number of cells increased from $5 \times 10^{3}$ to $2 \times 10^{5}$ cells per well (Fig. 1 ). Mean oestrogen secretion was 0.03 pg per cell per day at all cell

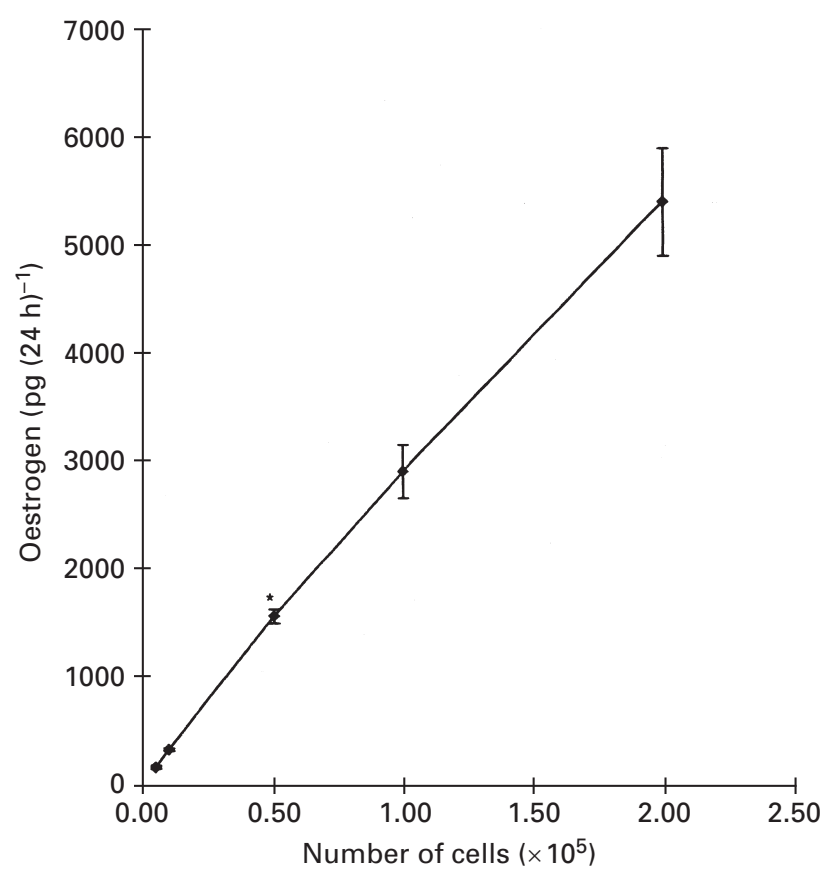

Fig. 1. Oestrogen production by dispersed embryonic cells in serum-free culture. Freshly collected day 13 horse embryos $(n=3)$ were dispersed, plated (in triplicate) at increasing numbers of cells per well, and incubated for $24 \mathrm{~h}$. Total oestrogen accumulation increased with number of cells from $5 \times 10^{3}$ cells per well to $2 \times 10^{5}$ cells per well in a linear fashion $\left(r^{2}=0.88\right.$; $y=117.7+0.027 x$ ). Data are expressed as mean \pm SEM of three replicates. ${ }^{*}$ For subsequent studies, $5 \times 10^{4}$ cells per well was chosen as a standard number of cells. concentrations. A standard of $5 \times 10^{4}$ cells per well was used in subsequent experiments. The profile of oestrogen accumulation from 0 to $48 \mathrm{~h}$ in serum-free culture and the rate of production during 6 or $12 \mathrm{~h}$ periods are shown (Fig. 2 ). The initial rapid rate of accumulation of $137.6 \mathrm{pg} \mathrm{h}^{-1}$ during the first $6 \mathrm{~h}$ period slowed $(P<0.05)$ to $76.7 \mathrm{pg} \mathrm{h}^{-1}$ during the second period (6-12 h) and reached a plateau by $24 \mathrm{~h}$ to $52.9 \mathrm{pg} \mathrm{h}^{-1}$. Between 24 and $48 \mathrm{~h}$ the rate of oestrogen production decreased $(P<0.05)$ to $19.4 \mathrm{pg} \mathrm{h}^{-1}$. Cell viability was initially greater than $95 \%$, decreased to $60 \%$ by $24 \mathrm{~h}$ and was $<50 \%$ at $48 \mathrm{~h}$. The rate of oestrogen production per viable cell was not significantly different at 6 and $24 \mathrm{~h}$; thus, a standard culture period of $24 \mathrm{~h}$ was chosen to evaluate treatment effects.

\section{Embryonic cell culture: dose-response studies}

Preliminary experiments using IGF-I supplementation from 0 to $500 \mathrm{ng} \mathrm{ml}^{-1}$ over 6,12 , 18, and $24 \mathrm{~h}$ culture periods revealed no significant dose-dependent effect on
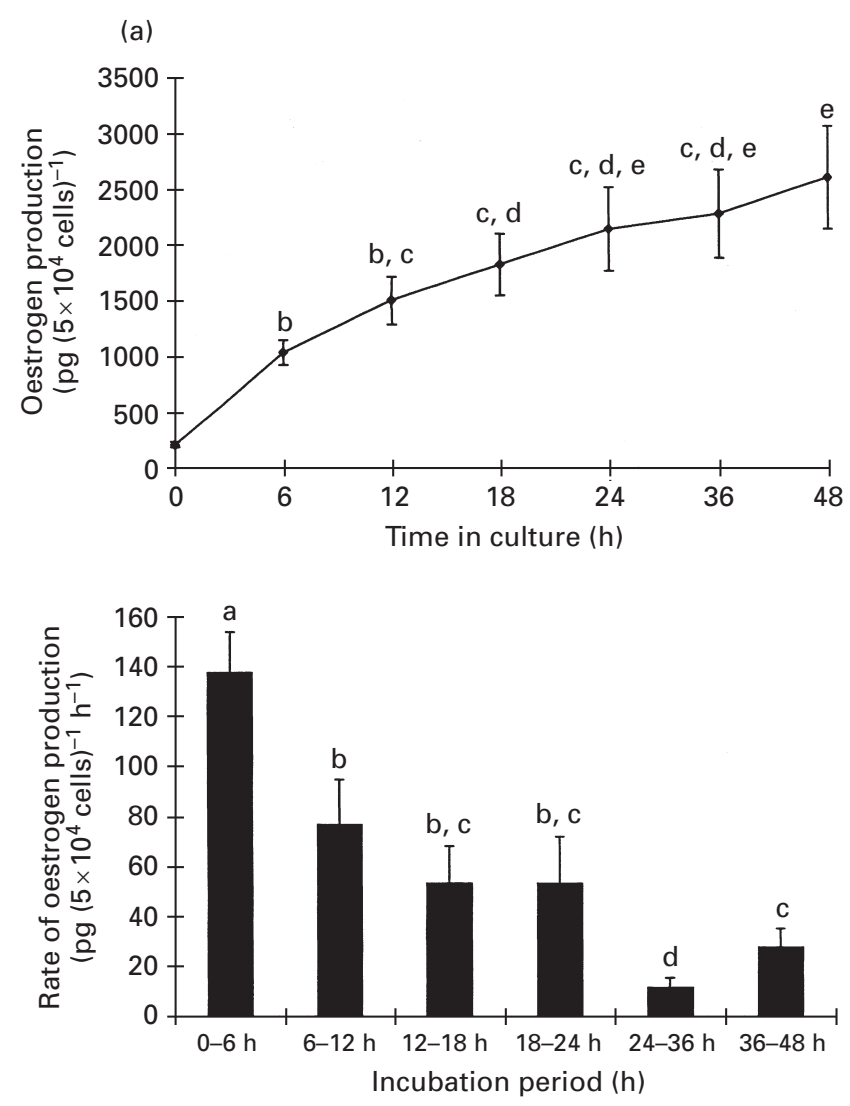

Fig. 2. Oestrogen production from 0 to $48 \mathrm{~h}$ by dispersed-cell cultures of blastocyst-stage (day 13$)$ horse embryos $(n=4)$. Data are expressed as mean \pm SEM of four replicate experiments and represent total accumulation over the culture period (a) and rate of accumulation over 6 and $12 \mathrm{~h}$ periods (b). Values without a common letter are significantly different $(P<0.05)$. For subsequent experiments, $24 \mathrm{~h}$ was chosen as a standard incubation period. 
basal oestrogen production at any time (data not shown). Supplementation with testosterone from 0 to $10 \mu \mathrm{g} \mathrm{m}^{-1}$ over $24 \mathrm{~h}$ culture (Fig. $3 \mathrm{a})$ resulted in increased $(P<0.001)$ oestrogen production to a maximum of $111.0 \mathrm{ng}$ per $5 \times 10^{4}$ cells from a basal $3.99 \mathrm{ng}$ per $5 \times 10^{4}$ cells. There was no additional increase in oestrogen production from 1 to $10 \mu \mathrm{g} \mathrm{ml}^{-1}$ testosterone. Similarly, supplementation with $0-10 \mu \mathrm{g}$ androstenedione $\mathrm{ml}^{-1}$ for $24 \mathrm{~h}$ (Fig. 3b) resulted in a maximal oestrogen production of $109.0 \mathrm{ng}$ per $5 \times 10^{4}$ cells at $10 \mu \mathrm{g}$ androstenedione $\mathrm{ml}^{-1}$, and this was not significantly different from oestrogen production at $1 \mu \mathrm{g}$ androstenedione $\mathrm{ml}^{-1}\left(107.45 \mathrm{ng}\right.$ per $5 \times 10^{4}$ cells). In each case, supplementation with androgen at $1 \mu \mathrm{g} \mathrm{ml}^{-1}$ resulted in maximal oestrogen production. At an aromatase-saturating dose of $1 \mu \mathrm{g}$ androstenedione $\mathrm{ml}^{-1}$, basal oestrogen production was $112 \mathrm{ng}$ per $5 \times 10^{4}$ cells per day with no significant dose-dependent effect of supplemental IGF-I from 0 to $100 \mathrm{ng} \mathrm{ml}^{-1}$ (Fig. 4).

(a)

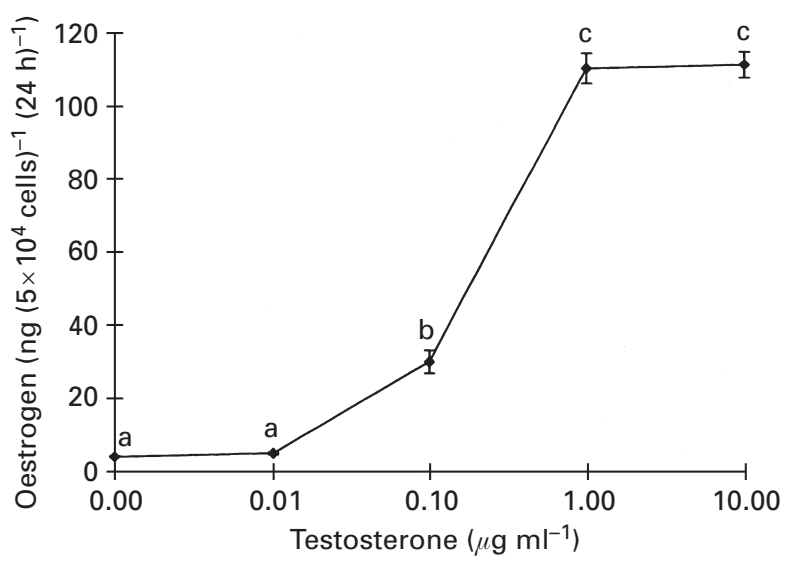

(b)

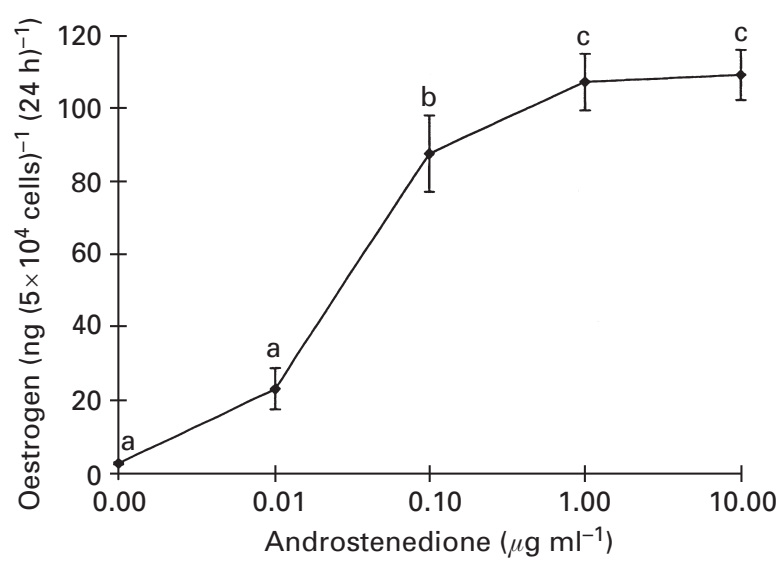

Fig. 3. Oestrogen production by dispersed-cell cultures of blastocyst-stage (day 13) horse embryos supplemented with testosterone (a) or androstenedione (b). Maximum aromatase activity was achieved at $1.0 \mu \mathrm{g} \mathrm{ml}^{-1}$ supplementation of either androgen. Data are expressed as mean $\pm \operatorname{SEM}(n=3)$. Values without a common letter are significantly different $(P<0.05)$.

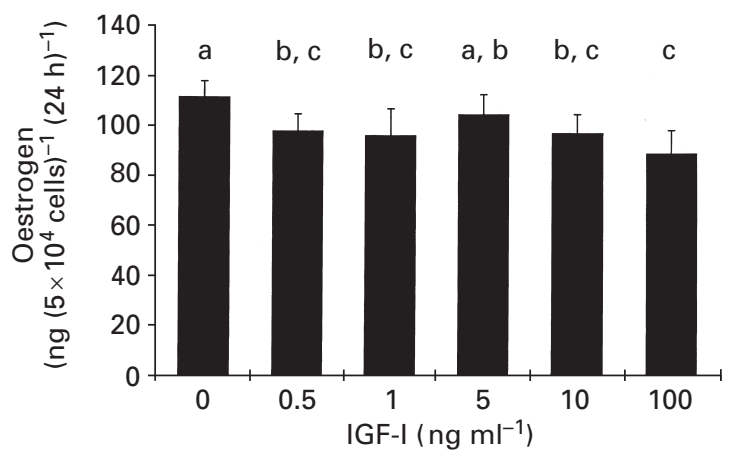

Fig. 4. Oestrogen production by dispersed-cell cultures of blastocyst-stage (day 13) horse embryos supplemented with $1.0 \mu \mathrm{g} \mathrm{ml}^{-1}$ androstenedione and insulin-like growth factor I (IGF-I) (0.5-100 $\left.\mathrm{ng} \mathrm{ml}^{-1}\right)$. No concentration-dependent effect of IGF-I was observed. Data are expressed as mean $\pm \operatorname{SEM}(n=3)$. Values without a common letter are significantly different $(P<0.05)$.

Insulin-like growth factor I in uterine flushings, endometrial biopsy tissue homogenates, blastocoelic fluid, and cultures of whole embryos and endometrial explants

Insulin-like growth factor I was detected in all uterine flushes analysed $(n=5)$ from day 13 pregnant mares. When corrected for volume, the total uterine content of IGF-I was $97.5 \pm 11.8 \mathrm{ng}$. Endometrial tissue concentration of IGF-I was $2.13 \pm 0.14 \mathrm{ng} \mathrm{mg}^{-1}$ for pregnant mares $(n=14)$ and not significantly different from $2.15 \pm$ $0.15 \mathrm{ng} \mathrm{mg}^{-1}$ in non-pregnant mares $(n=8)$. Blastocoelic content of IGF-I in day 13 embryos was $1.26 \pm 0.14 \mathrm{ng}$ $(n=9)$. Mean secretion of IGF-I by intact embryos $(n=3)$ in serum-free medium was $0.84 \pm 0.2 \mathrm{ng} \mathrm{h}^{-1}$. Endometrial explant secretion $(n=7)$ of IGF-I was $10.1 \pm 0.9 \mathrm{pg} \mathrm{mg}^{-1} \mathrm{~h}^{-1}$.

\section{Endometrial IGF-I production with and without supplemental oestradiol}

Endometrial secretion of IGF-I in explant cultures incubated for 24 ( $n=3$ experiments), $48(n=3)$ and $72 \mathrm{~h}$ $(n=1)$ without oestradiol supplementation is shown (Fig. 5). The mean IGF-I secretion rate during $24 \mathrm{~h}$ culture was $10.33 \mathrm{pg} \mathrm{mg}^{-1} \mathrm{~h}^{-1}$ for a total of $0.25 \mathrm{ng} \mathrm{mg}^{-1}$. Over $48 \mathrm{~h}$, the mean secretion rate was $8.36 \mathrm{pg} \mathrm{mg}^{-1} \mathrm{~h}^{-1}$, totalling $0.40 \mathrm{ng} \mathrm{mg}^{-1}$. Secretion of IGF-I averaged $11.51 \mathrm{pg} \mathrm{mg}^{-1} \mathrm{~h}^{-1}$ during the $72 \mathrm{~h}$ culture. In the oestradiol dose-response studies, accumulation of IGF-I at $48 \mathrm{~h}$ in the control group was $0.40 \pm 0.22 \mathrm{ng} \mathrm{mg}^{-1}$ and was not modulated by supplemental oestradiol at 0-10 $\mu \mathrm{g} \mathrm{ml}^{-1}$. Similarly, no dosedependent effect was observed during the 24 or $72 \mathrm{~h}$ periods (data not shown).

\section{Discussion}

This study is the first to describe an in vitro cell culture system for the study of steroidogenesis in the equine 


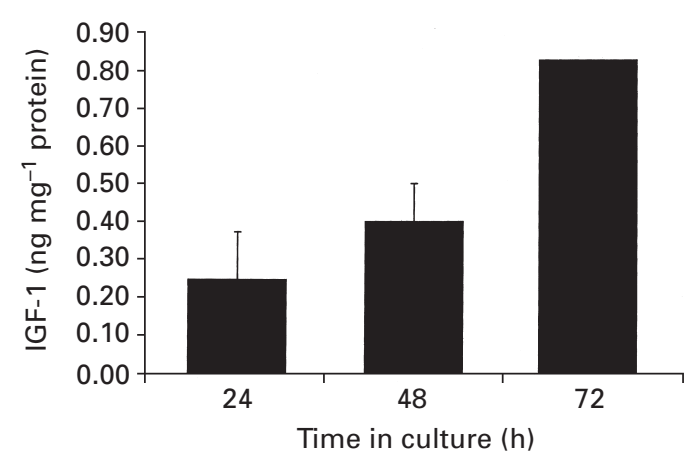

Fig. 5. Accumulation of insulin-like growth factor I (IGF-I) in serum-free cultures of endometrial explants from pregnant mares. Endometrial biopsies taken at day 13 of pregnancy were minced and cultured in serum-free medium for 24 ( $n=3$ experiments), 48 $(n=3)$ and $72 \mathrm{~h}(n=1)$. Mean endometrial secretion of IGF-I was $0.01 \mathrm{ng} \mathrm{mg}^{-1} \mathrm{~h}^{-1}$ at each time. Data are expressed as mean \pm SEM.

embryo, and test definitively the role of IGF-I in the control of oestrogen synthesis. The results demonstrate that IGF-I is of both embryonic and endometrial origin during early pregnancy in mares, but do not support the model of a positive 'feed forward' system between IGF-I and embryonic oestrogen secretion. Exogenous IGF-I did not significantly enhance oestrogen production or P450arom activity in cultured equine embryonic cells (day 13) with or without supplemental androstenedione. Reciprocally, oestrogen had no effect on IGF-I secretion from endometrial explants. Although it is difficult to extrapolate data from in vitro studies directly to the in vivo situation, the present data indicate that the model for maternal-conceptus signalling in mares is different from that proposed for pigs.

The lack of a dose-dependent stimulation of oestrogen production by IGF-I in the initial studies may reflect a shortage of substrate IGF-IR or other regulatory factors in the serum-free environment. A saturating dose of androstenedione was provided in subsequent experiments to test more definitively the effect of IGF-I on P450arom activity. The lack of a dose-dependent response under these conditions clearly demonstrates that IGF-I does not stimulate P450arom activity in day 13 equine embryos under these culture conditions. It is possible that the equine conceptus does not express IGF-IR at this stage and is therefore unable to respond to IGF-I stimulation; however, this seems unlikely given the fact that IGF-IR is widely expressed in other mammalian embryos (Simmen et al., 1995). Results in pigs indicate that IGF-I modulates P450arom activity (Hofig et al., 1991) and expression (Ko et al., 1994; Green et al., 1995) in the preimplantation embryo, but an IGF-I-stimulated increase in oestrogen production from pig conceptus tissues has not been demonstrated in vitro.

The observation that addition of androstenedione or testosterone as substrate for P450arom leads to increased oestrogen production by equine embryonic cells indicates that P450arom is not rate-limiting in the day 13 equine conceptus. This conclusion is supported by immunocytochemical and in situ hybridization data showing high P450arom expression in the trophectoderm at this developmental stage (Walters et al., 2000). Therefore, the rate of oestrogen production is dictated by the precursor pool from earlier steps in steroidogenesis. The limiting step is not known. If oestrogen biosynthesis is a regulated process in the equine embryo, it is likely to be at an earlier point in the steroidogenic pathway. Evidence from work in the ovary indicates that IGF-I regulates the expression and activity of multiple steroidogenic enzymes (for review, see Hammond et al., 1991) including P450scc (Veldhuis et al., 1986; Magoffin et al., 1990; Magoffin and Weitsmann, 1993a; Urban et al., 1994), 3ß-hydroxysteroid dehydrogenase (Magoffin and Weitsman, 1993b; deMoura et al., 1997), and P450c17 (deMoura et al., 1997) in addition to P450arom (Adashi et al., 1985; Erickson et al., 1989). It is possible that IGF-I influences expression or activity of these enzymes in the equine blastocyst.

Support for the use of this dispersed cell culture protocol for study of embryonic steroidogenesis in horses comes from a number of observations. First, the use of dispersed cells allows for multiple treatments to be applied to one embryo, greatly reducing the error due to individual variation noted by Choi et al. (1997), and allows for optimal use of a small number of scarce embryos. Second, oestrogen production by cells in this serum-free culture system is comparable to that of whole embryos. Choi et al. (1997) reported that mean oestrogen production by whole day 13.5 embryos was $6.33 \mathrm{fg}$ per cell per $2 \mathrm{~h}$ over the first $12 \mathrm{~h}$ of culture $(10 \%$ FCS) compared with $7.30 \mathrm{fg}$ per cell per $2 \mathrm{~h}$ over the same time period in dispersed-cell cultures. These results indicate that equine embryonic cells are capable of considerable oestrogen synthesis in the absence of exogenous steroid or lipoprotein, and that they have the capacity for de novo cholesterol synthesis or substantial intracellular lipoprotein stores. Evidence of significant lipid storage and metabolism has been observed in cells of the preimplantation equine embryo (Flood et al., 1982).

The conclusion that IGF-I in the uterine lumen of pregnant mares is of both endometrial and embryonic origin is supported by these results. Endometrial secretion represents the major source of luminal IGF-I with the potential for a significant contribution coming from the preimplantation embryo. The concentration of IGF-I in uterine flush fluid collected on day 13 of pregnancy $(97.5 \mathrm{ng}$ ) is in close agreement with results of Salute and Tucker (1992), who reported a mean of $0.146 \mathrm{ng} I G F-I \mathrm{ml}^{-1}$ in flushes $(500 \mathrm{ml})$ collected on days $12,14,16$ and $17(0.146 \times 500 \mathrm{ml}=$ $73 \mathrm{ng})$. Similarly, mean IGF-I in the BF of day 13 embryos $\left(1.21 \mathrm{ng} \mathrm{m}^{-1}\right)$, although somewhat higher, is comparable with values reported (Salute and Tucker, 1992) for the yolk sac fluid content of day 14 and day 17 equine conceptuses (0.21 ng ml-1 and $0.81 \mathrm{ng} \mathrm{ml}^{-1}$, respectively). Secretion of IGF-I by the intact day 13 embryo $\left(0.84 \mathrm{ng} \mathrm{ml}^{-1}\right)$ appears 
to be higher than that reported for conceptus membranes (Salute and Tucker, 1992). This result is not surprising as embryonic dispersed-cell cultures under the same culture conditions as intact embryos did not produce detectable amounts of IGF-I at cell concentrations as high as $2 \times 10^{6}$ cells per well (K. W. Walters, unpublished). It is possible that disruption of the embryo significantly reduces the capacity for IGF-I synthesis and secretion, but this is not the case with conceptus oestrogen production. Oestrogen production by dispersed cells in serum-free culture is comparable on a per-cell basis to that of intact embryos. It is possible that embryonic synthesis of IGF-I requires more complex intercellular interactions that are disrupted by collapse or dispersal of the embryo. It is also possible, but unlikely, that IGF-I measured in the whole embryoconditioned medium was of maternal origin and sequestered in the BF. The amount of IGF-I produced by intact embryos during a $24 \mathrm{~h}$ culture was considerably higher than that measured in the BF.

The present data indicate that endometrial synthesis of IGF-I is not directly stimulated by conceptus oestrogen during early (day 13) pregnancy in mares. Consistent with this conclusion is the lack of endometrial response in vitro to exogenous oestradiol and the finding of similar tissue concentrations of IGF-I in pregnant and non-pregnant mares. Endometrial responsiveness and hence IGF-I secretion may be influenced by the status of oestrogen receptors. Initial studies in mares showed no difference in oestrogen receptor protein between early pregnancy (day 15) and dioestrus (Tomanelli et al., 1991; Watson et al., 1992). McDowell et al. (1999) reported that endometrial mRNA encoding oestrogen receptor $\alpha$ was significantly lower at day 15 of pregnancy than it was in comparable non-pregnant tissue. The downregulation of oestrogen receptor $\alpha$ may affect the uterine response to oestrogen during early pregnancy in mares. The potential for a conceptus-secreted factor to regulate endometrial oestrogen receptor concentrations in mares is intriguing given the evidence in ruminant species for the downregulation of oestrogen receptor and oxytocin $\mathrm{R}$ by conceptus interferon- $\tau$ (Spencer and Bazer, 1995, 1996).

It has been suggested that IGF-I serves as an important autocrine-paracrine signal during early pregnancy to coordinate pregnancy recognition and conceptus development (Simmen et al., 1995). In pigs, IGF-I may act as a paracrine signal from the uterus to coordinate events associated with MRP. Hofig et al. (1991) demonstrated that IGF-I, but not insulin, stimulates P450arom activity in the day 12 pig conceptus. Green et al. (1995) found that IGF-I stimulated expression of P450arom mRNA in day 12 filamentous conceptuses but inhibited expression in small spherical embryos of the same age. These results indicate a role for IGF-I in the regulation of oestrogen synthesis in pig embryos but also suggest that additional modulatory factors are involved.

In summary, this report provides a serum-free cell culture system for the study of steroid production in the horse conceptus and demonstrates that oestrogen biosynthesis in the preimplantation equine embryo is not regulated by IGF-I at the level of P450arom activity. The results further indicate that IGF-I in the uterine lumen of mares during early pregnancy is of endometrial and conceptus origin, and that secretion is not oestrogen-dependent. The significant production and storage of IGF-I within the blastocoel cavity implies an important role for this growth factor. Additional work is needed to reveal the mechanisms for the control of embryonic steroidogenesis and to clarify the role of IGF-I in autocrine-paracrine signalling for the successful maintenance of pregnancy in mares.

The authors gratefully acknowledge Tom Famula for assistance with statistical analysis, Ken Taylor, Hilary Ward and the stallion managers for horse breeding and embryo collection and the technical support of Alice Moyer and Lil Sibley. This project was supported by the Center for Equine Health, University of California, Davis with funds provided by the Oak Tree Racing Association, the State of California satellite wagering fund and contributions by private donors.

\section{References}

Adashi EY, Resnick CE, Brodie AM, Svoboda ME and Van Wyk JJ (1985) Somatomedin-C-mediated potentiation of follicle-stimulating hormoneinduced aromatase activity of cultured rat granulosa cells Endocrinology 117 2313-2320

Adesanya OO, Zhou J and Bondy CA (1996) Sex steroid regulation of insulin-like growth factor system gene expression and proliferation in primate myometrium Journal of Clinical Endocrinology and Metabolism 81 1967-1974

Baxter RC, Brown AS and Turtle JR (1982) Radioimmunoassay for somatomedin-c: comparison with radioreceptor assay in patients with growth hormone disorders, hypothyroidism, and renal failure Clinical Chemistry 28 488-495

Bazer FW and Thatcher WW (1977) Theory of maternal recognition of pregnancy in swine based on estrogen controlled endocrine versus exocrine secretion of prostaglandin $F_{2 \alpha}$ by the uterine endometrium Prostaglandins 14 397-401

Choi SJ, Anderson GB and Roser JF (1997) Production of free estrogens and estrogen conjugates by the preimplantation equine embryo Theriogenology 47 457-466

Conley AJ, Christenson LK, Ford SP and Christenson RK (1994) Immunocytochemical localization of cytochromes P450 17 $\alpha$-hydroxylase and aromatase in embryonic cell layers of elongating porcine blastocysts Endocrinology 135 2248-2254

deMoura M D, Choi D, Adashi E Y and Payne DW (1997) Insulin-like growth factor-I-mediated amplification of follicle-stimulating hormonesupported progesterone accumulation by cultured rat granulosa cells: Enhancement of steroidogenic enzyme activity and expression Biology of Reproduction 56 946-953

England BG, Niswender GD and Midgley AR, Jr (1974) Radioimmunoassay of estradiol-17 $\beta$ without chromatography Journal of Clinical Endocrinology and Metabolism 38 42-50

Erickson GF, Garzo VG and Magoffin DA (1989) Insulin-like growth factor I regulates aromatase activity in human granulosa and granulosa luteal cells Journal of Clinical Endocrinology and Metabolism 69 $716-724$

Flood PF, Betteridge KJ and Irvine DS (1979) Oestrogens and androgens in blastocoelic fluid and cultures of cells from equine conceptuses of 10-22 days gestation Journal of Reproduction and Fertility Supplement 27 413-420

Flood PF, Betteridge KJ and Diocee MS (1982) Transmission electron microscopy of horse embryos 3-16 days after ovulation Journal of Reproduction and Fertility Supplement 32 319-327 
Freeman DA, Woods GL, Vanderwall DK and Weber JA (1992) Embryoinitiated oviductal transport in mares Journal of Reproduction and Fertility 95 535-538

Geisert RD and Conley AJ (1998) Secretion and metabolism of steroids in subprimate mammals during pregnancy. In Contemparary Endocrinology 9. Endocrinology of Pregnancy pp 291-318 Ed. FW Bazer. Humana Press, Totowa, NJ

Goff AK, Renard A and Betteridge KJ (1983) Regulation of steroid synthesis in pre-attachment equine embryos Biology of Reproduction 28137

Green ML, Simmen RCM and Simmen FA (1995) Developmental regulation of steroidogenic enzyme gene expression in the periimplantation porcine conceptus: a paracrine role for insulin-like growth factor I Endocrinology 136 3961-3970

Hammond JM, Mondschein JS, Samaras SE, Smith SA and Hagan DR (1991) The ovarian insulin-like growth factor system Journal of Reproduction and Fertility Supplement 43 199-208

Heap RB, Hamon MH and Allen WR (1991) Oestrogen production by the preimplantation donkey conceptus compared with that of the horse and the effect of between-species embryo transfer Journal of Reproduction and Fertility 93 141-147

Hofig A, Simmen RCM, Bazer F W and Simmen FA (1991) Effects of insulin-like growth factor I on aromatase cytochrome P450 activity and oestradiol biosynthesis in preimplantation porcine conceptuses in vitro. Journal of Endocrinology 130 245-250

Jordan MF (1995) Effects of Age and Fertility on Plasma and Testicular Insulin-like Growth Factor 1 (IGF-I) Concentrations in Stallions MS Thesis, University of California, Davis

Kenney RM (1978) Cyclic and pathological changes in the mare endometrium as detected by biopsy, with a note on early embryonic death Journal of the American Veterinary Medical Association 172 241-262

Ko Y, Choi I, Green ML, Simmen FA and Simmen RCM (1994) Transient expression of the cytochrome P450 aromatase gene in elongating porcine blastocysts is correlated with uterine insulin-like growth factor levels during peri-implantation development Molecular Reproduction and Development 37 1-11

Letcher R, Simmen RCM, Bazer FW and Simmen FA (1989) Insulin-like growth factor I expression during early conceptus development in the pig Biology of Reproduction 41 1143-1151

McDowell KJ, Adams MH, Adam CY and Simpson KS (1999) Changes in equine endometrial oestrogen receptor $\alpha$ and progesterone receptor mRNAs during the oestrous cycle, early pregnancy and after treatment with exogenous steroids Journal of Reproduction and Fertility 117 135-142

Magoffin DA and Weitsmann SR (1993a) Effect of insulin-like growth factor I on cholesterol side-chain cleavage cytochrome P450 messenger ribonucleic acid expression in ovarian theca-interstitial cell stimulated to differentiate in vitro. Molecular and Cellular Endocrinology 96 45-51

Magoffin DA and Weitsmann SR (1993b) Insulin-like growth factor I stimulates expression of $3 \beta$-hydroxysteroid dehydrogenase messenger ribonucleic acid in ovarian theca-interstitial cells Biology of Reproduction 48 1166-1173

Magoffin DA, Kurtz KM and Erickson GF (1990) Insulin-like growth factor I selectively stimulates cholesterol side-chain cleavage expression in ovarian theca-interstitial cells Molecular Endocrinology 4 489-496

Murphy LJ and Ghahary A (1990) Uterine insulin-like growth factor I: regulation of expression and its role in estrogen-induced uterine proliferation Endocrine Reviews 11 443-453

Murphy LJ, Murphy LC and Friesen HG (1987) Estrogen induces insulinlike growth factor I expression in the rat uterus Molecular Endocrinology 1 445-450

Perry JS, Heap RB and Amoroso EC (1973) Steroid hormone production by pig blastocysts Nature 245 45-47

Pinaud MA, Roser JF and Dybdal N (1991) Gonadotropin-releasing hormone $(\mathrm{GnRH})$ induced luteinizing hormone $(\mathrm{LH})$ secretion from perifused equine pituitaries Domestic Animal Endocrinology 8 353-368

Powell SA, Tim, KI, Smith BB and Menino AR (1999) Estradiol production by the preimplantation Ilama embryo and the effect of estradiol on luteal lifespan Biology of Reproduction 60249

Roberts RM, Xie S and Trout WE (1993) Embryo-uterine interactions in pigs during week 2 of pregnancy Journal of Reproduction and Fertility Supplement 48 171-186

Roberts RM, Xie S and Mathialagan N (1996) Maternal recognition of pregnancy Biology of Reproduction 54 294-302

Salute ME and Tucker KE (1992) Insulin-like growth factor I (IGF-I) in yolk sac fluid, uterine flush and conceptus conditioned media during early pregnancy in mares Biology of Reproduction 4668

Schultz GA and Heyner S (1993) Growth factors in preimplantation mammalian embryos Oxford Reviews of Reproductive Biology 15 1543-1581

Sharp DC, McDowell KJ, Weithenauer J and Thatcher WW (1989) The continuum of events leading to maternal recognition of pregnancy in mares Journal of Reproduction and Fertility Supplement 37 101-107

Simmen RCM, Ko Y and Simmen FA (1993) Insulin-like growth factors and blastocyst development Theriogenology 39 163-175

Simmen RCM, Green ML and Simmen FA (1995) IGF system in periimplantation uterus and embryonic development. In Molecular and Cellular Aspects of Periimplantation Processes pp 185-204 Ed. SK Dey. Springer-Verlag, New York

Skidmore JA, Allen WR and Heap RB (1994) Oestrogen synthesis by the peri-implantation conceptus of the one-humped camel (Camelus dromedaries) Journal of Reproduction and Fertility 101 363-367

Spencer TE and Bazer FW (1995) Temporal and spatial alterations in uterine estrogen receptor gene expression during the estrous cycle and early pregnancy in the ewe Biology of Reproduction 53 1527-1543

Spencer TE and Bazer FW (1996) Ovine interferon tau suppresses transcription of the estrogen receptor and oxytocin receptor genes in the ovine endometrium Endocrinology 137 1144-1147

Tomanelli RN, Sertich PL and Watson ED (1991) Soluble oestrogen and progesterone receptors in the endometrium of the mare Journal of Reproduction and Fertility Supplement 44 267-273

Urban RJ, Shupnik MA and Bodenburg YH (1994) Insulin-like growth factor I increases expression of the porcine P450 cholesterol side chain cleavage gene through a GC rich domain Journal of Biological Chemistry $26925761-25769$

Veldhuis JD, Rodgers RJ, Dee A and Simpson ER (1986) The insulin-like growth factor, somatomedin-C, induces the synthesis of cholesterol side-chain cleavage cytochrome P450 and adrenodoxin in ovarian cells Journal of Biological Chemistry 261 2499-2503

Walters KW (1998) Maternal-Conceptus Communication during Early Pregnancy: Estrogen and Insulin-like Growth Factor I PhD Dissertation, University of California, Davis

Walters KW, Corbin CJ, Anderson GB, Roser JF and Conley AJ (2000) Tissue-specific localization of cytochrome P450 aromatase in the equine embryo by in situ hybridization and immunocytochemistry Biology of Reproduction 62 1141-1145

Watson AJ, Hogan A, Hahnel A, Wiemer KE and Schultz GA (1992 Expression of growth factor ligand and receptor genes in the preimplantation bovine embryo Molecular Reproduction and Development $3187-95$

Watson AJ, Watson PH, Arcellana-Panlilio M, Warnes D, Walker SK, Schultz GA, Armstrong DT and Seamark RF (1994) A growth factor phenotype map for ovine preimplantation development Biology of Reproduction $\mathbf{5 0} 725-733$

Watson ED, Skolnik SB, Zanecosky HG (1992) Progesterone and estrogen receptor distribution in the endometrium of the mare Theriogenology 38 575-580

Zavy MT, Mayer R, Vernon MW, Bazer FW and Sharp DC (1979) An investigation of the uterine luminal environment of non-pregnant and pregnant pony mares Journal of Reproduction and Fertility, Supplement 27 403-411

Zhang X, Rutledge J, Watson AJ, Schultz GA and Armstrong DT (1992) Gene expression for insulin-like growth factor I (IGF-I) and the receptors for IGF-I and insulin during the preimplantation period in the rat Biology of Reproduction 4679 